\title{
Seasonal variation in the histology of the testis of the red deer, Cervus elaphus
}

\author{
Marie-Therèse Hochereau-de Reviers and G. A. Lincoln* \\ I.N.R.A., Laboratoire de Fertilité Mâle, Station de Physiologie de la Reproduction, \\ 37380 Nouzilly, France, and *M.R.C. Unit of Reproductive Biology, 2 Forrest Road, \\ Edinburgh EHI $2 Q W$, U.K.
}

\begin{abstract}
Summary. A histological study of the testes of stags shot in autumn (sexual season) and spring (quiescent period) indicated that the 3-fold increase in testicular size observed in the autumn was accompanied by increases in nearly all features studied (volumes of intertubular tissue, Leydig cells, blood vessels and peritubular cells; diameter and length of seminiferous tubules; the number of $A_{1}$ spermatogonia and products of spermatogonial divisions, meiosis and spermiogenesis). There were, however, fewer $\mathbf{A}_{0}$ spermatogonia in the testes in autumn.
\end{abstract}

\section{Introduction}

Seasonal changes in the testis of the red deer, Cervus elaphus, have been reported previously (Frankenberger, 1953; Bruggerman, Adam \& Karg, 1965; Lincoln, 1971a, b) but no precise analysis of the variations is available. The object of the present work was to describe in detail the changes which occur in the cellular components of the testes during the year, and to correlate these with the hormonal status of the animals.

\section{Materials and Methods}

Adult red deer stags were shot in the spring (February, March and April) during the non-sexual season $(N=5)$ or at the end of summer and beginning of autumn (August, September and October) during the sexual season $(N=6)$. Dissection of the animals and recovery of tissues was as described previously (Lincoln, 1971b). Frozen samples of seminal vesicles were assayed for fructose by a colorimetric method (Lindner \& Mann, 1960). The samples of testicular tissue were assayed for testosterone by a specific gas chromatographic technique (Mann, Rowson, Short \& Skinner, 1967), and the blood serum levels of LH were determined by radioimmunoassay (Scaramuzzi, Caldwell \& Moor, 1970). The LH assay used ovine NIH-LH-S14 as reference standard, and the sensitivity was $0.5 \mathrm{ng} / \mathrm{ml}$.

Fragments of testicular tissue were fixed in Bouin's solution, and embedded in paraffin wax and $10 \mu \mathrm{m}$ sections were cut for histological study. The cycle of the seminiferous epithelium was classified in the eight stages described by Roosen-Runge \& Giesel (1950) for the rat.

The type A spermatogonia and the Sertoli cells were counted in 10 cross-sections of seminiferous tubules at stages 7, 8 and 1, and leptotene primary spermatocytes, round spermatids and elongated spermatids were counted in 10 cross-sections at stages 1,8 and 7 respectively. The total counts for each cell type were corrected for differences in nuclear volume by the formula of Abercrombie (1946) as modified by Ortavant (1958), although no correction was made for the Sertoli cells and elongating spermatids which were irregular in form. The nuclear and nucleolar diameters of $A_{0}$ and $A_{1}$ spermatogonia (Clermont, 1967) were measured with an ocular micrometer on 10 nuclei per cell type. The diameter of the tubules was measured on 20 cross-sections per testis. The relative volume of the intertubular tissue and seminiferous tubules was determined with a 25-point ocular integrator 
(Hennig, 1957) on 20 microscope fields for each testis. The relative proportion of Leydig cells, blood vessels, peritubular cells and fibrolasts in the peritubular tissue was determined with the same method. The diameter of the Leydig cell cytoplasm was measured in 10 randomly selected cells per animal and the mean cell volume was determined.

The total length of the seminiferous tubules/testis was calculated from the above data by the formula of Attal \& Courot (1963). The total number of type $A_{0}$ and $A_{1}$ spermatogonia per testis was calculated from the total length of the seminiferous tubules and the mean corrected number of cells per $10 \mu \mathrm{m}$ tubular cross-section. The yield of spermatogonial divisions was determined from the ratio of primary spermatocytes at leptotene to $A_{1}$ spermatogonia, the yield of meiosis was determined from the ratio of round spermatids (stage 8) to primary spermatocytes at leptotene, and the yield of spermiogenesis from the ratio of elongated spermatids (stage 7) to round spermatids (stage 8). Statistical comparisons were made throughout by analysis of variance (Snedecor \& Cochran, 1957).

\section{Results}

As shown in Table 1 all the reproductive characteristics that were measured were greater in the autumn-killed animals than in the spring-killed animals except for the testicular testosterone content which varied greatly between animals.

Table 1. Comparisons of various characteristics (mean \pm s.e.m.) of red deer stags shot in spring and autumn

\begin{tabular}{lccc}
\hline & $\begin{array}{c}\text { Spring } \\
(\mathrm{N}=5)\end{array}$ & $\begin{array}{c}\text { Autumn } \\
(\mathrm{N}=6)\end{array}$ & Significance \\
\hline & & & \\
Age (years) & $6.4 \pm 0.4$ & $7.5 \pm 0.9$ & N.S. \\
Body weight (kg) & $91.5 \pm 1.9$ & $104.6 \pm 5.8$ & N.S. \\
Pituitary weight (g) & $1.09 \pm 0.04$ & $1.41 \pm 0.04$ & $P<0.01$ \\
Plasma LH (ng/ml) & $4.5 \pm 0.6$ & $7.3 \pm 0.5$ & $P<0.05$ \\
Testis (left only) & & & \\
Weight (g) & $24.4 \pm 2.7$ & $70.7 \pm 7.5$ & $P<0.01$ \\
Intertubular tissue vol. $\left(\mathrm{cm}^{3}\right)$ & $5.4 \pm 0.5$ & $13.5 \pm 1.6$ & $P<0.01$ \\
Seminiferous tubule length $(\mathrm{m})$ & $1273 \pm 72$ & $2487 \pm 325$ & $P<0.01$ \\
Seminiferous tubule diam. $(\mu \mathrm{m})$ & $137 \pm 5.3$ & $180 \pm 8.5$ & $P<0.01$ \\
Testosterone content $(\mu \mathrm{g})$ & $3.4 \pm 2.8$ & $265.6 \pm 136.9$ & N.S. \\
Seminal vesicles & & & \\
Total weight $(\mathrm{g})$ & $19.9 \pm 1.0$ & $54.5 \pm 11.7$ & $P<0.05$ \\
Fructose content (mg) & $3.9 \pm 0.5$ & $168.8 \pm 57.7$ & $P<0.05$ \\
& & & \\
\hline
\end{tabular}

The relative frequency of the seminiferous epithelium stages was similar for the animals shot in both seasons (Table 2). The total number of Sertoli cells/testis and the size of the Sertoli cell nucleus did not differ significantly in the two groups of animals (Tables 3 and 4). Two types of stem spermatogonia were recognized; Type $A_{0}$ spermatogonia had a round and pale nucleus with granular chromatin and 1 or 2 nucleoli (mean \pm s.e.m. nuclear and nucleolar diameter $=7.5 \pm 0.02$ and $1.6 \pm$ $0.01 \mu \mathrm{m}$ respectively) and an eccentricity coefficient of the nucleus of $0.89 \pm 0.02$. Type $A_{1}$ spermatogonia had a pale and ovoid nucleus, fine granular chromatin and one central spherical nucleolus (nuclear and nucleolus diameter $=8.6 \pm 0.04$ and $2.5 \pm 0.01 \mu \mathrm{m}$ respectively, and an eccentricity coefficient of the nucleus of $0.73 \pm 0.04$ ). The nuclear and nucleolar size were larger and the eccentricity coefficient lower in $A_{1}$ compared to $A_{0}$ spermatogonia. The total number of $A_{0}$ spermatogonia/testis was significantly less in the testes fromautumn-killed animals. The seasonal difference in the total number of $A_{1}$ spermatogonia/testis was less conspicuous, although $\mathbf{A}_{1}$ stem cells tended to be more numerous in the autumn (Table 3 ). 
Table 2. Relative frequencies of the stages of the seminiferous epithelium in red deer stags culled in spring (N=5) and autumn $(\mathbf{N}=6)$

\begin{tabular}{lrccccccc}
\hline & \multicolumn{8}{c}{ Stage } \\
\cline { 2 - 8 } Season & 1 & 2 & 3 & 4 & 5 & 6 & 7 & 8 \\
\hline Spring & $22.7 \pm 2.5$ & $8.7 \pm 1.4$ & $23.7 \pm 1.3$ & $9.1 \pm 1.4$ & $4.5 \pm 1.3$ & $20.7 \pm 1.2 *$ & $10.9 \pm 1.1$ \\
Autumn & $26.3 \pm 1.9$ & $10.0 \pm 1.4$ & $20.8 \pm 1.6$ & $9.9 \pm 1.0$ & $2.8 \pm 0.8$ & $10.9 \pm ! \cdot 4$ & $8.7 \pm 0.7$ & $10.3 \pm 1.2$ \\
\hline
\end{tabular}

* During the non-sexual season stages 6 and 7 cannot be clearly defined and are counted together.

Table 3. Seasonal variations of total numbers of Sertoli cells and stem spermatogonia per testis and of yields of spermatogenesis in the red deer stag

\begin{tabular}{|c|c|c|c|}
\hline & \multicolumn{2}{|c|}{ Season } & \multirow[b]{2}{*}{ Significance } \\
\hline & $\begin{array}{l}\text { Spring } \\
(N=5)\end{array}$ & $\begin{array}{l}\text { Autumn } \\
(\mathrm{N}=6)\end{array}$ & \\
\hline Sertoli cells/testis $\left(\times 10^{6}\right)$ & $340 \cdot 2 \pm 34 \cdot 6$ & $463 \cdot 5 \pm 41 \cdot 4$ & N.S. \\
\hline $\mathrm{A}_{0}$ spermatogonia/testis $\left(\times 10^{6}\right)$ & $57 \cdot 6 \pm 4.8$ & $31 \cdot 8 \pm 4 \cdot 5$ & $P<0.01$ \\
\hline$A_{1}$ spermatogonia/testis $\left(\times 10^{6}\right)$ & $37.0 \pm 5.7$ & $48.7 \pm 6.6$ & N.S. \\
\hline $\begin{array}{l}\text { Leptotene I spermatocytes: } \\
\text { A }_{1} \text { spermatogonia }\end{array}$ & $4 \cdot 6 \pm 1.9$ & $14 \cdot 2 \pm 2 \cdot 3$ & $P=0.01$ \\
\hline $\begin{array}{l}\text { Round spermatids (Stage 8): } \\
\text { leptotene I spermatocytes }\end{array}$ & $2.8 \pm 0.3$ & $3.3 \pm 0.5$ & N.S. \\
\hline $\begin{array}{l}\text { Elongated spermatids (Stage 7): } \\
\text { round spermatids (Stage 8) }\end{array}$ & $0.43 \pm 0.17$ & $0.93 \pm 0.15$ & $P=0.05$ \\
\hline
\end{tabular}

Table 4. Seasonal variation in the size of various structural components of the testis in the red deer stag

\begin{tabular}{|c|c|c|c|}
\hline & \multicolumn{2}{|c|}{ Season } & \multirow[b]{2}{*}{ Significance } \\
\hline & $\begin{array}{r}\text { Spring } \\
(\mathrm{N}=5)\end{array}$ & $\begin{array}{l}\text { Autumn } \\
(\mathrm{N}=6)\end{array}$ & \\
\hline \multicolumn{4}{|l|}{ Sertoli cells } \\
\hline Nuclear area $\left(\mu \mathrm{m}^{2}\right)$ & $54.3 \pm 1.81$ & $53 \cdot 4 \pm 2 \cdot 11$ & N.S. \\
\hline \multicolumn{4}{|l|}{ Leydig cells } \\
\hline Nuclear area $\left(\mu \mathrm{m}^{2}\right)$ & $20.7 \pm 1.69$ & $28.8 \pm 1.01$ & $P<0.01$ \\
\hline Cytoplasmic volume $\left(\mu \mathrm{m}^{3}\right)$ & $7055 \pm 403$ & $13544+403$ & $P<0.01$ \\
\hline Total volume of tissue $\left(\mathrm{cm}^{3}\right)$ & $2 \cdot 13 \pm 0.15$ & $6.06 \pm 0.94$ & $P<0.01$ \\
\hline \multicolumn{4}{|l|}{ Fibroblastic cells } \\
\hline Total volume of tissue $\left(\mathrm{cm}^{3}\right)$ & $1.66 \pm 0.26$ & $3.91 \pm 0.55$ & $P=0.01$ \\
\hline \multicolumn{4}{|l|}{ Blood vessels } \\
\hline Total volume of tissue $\left(\mathrm{cm}^{3}\right)$ & $0.45 \pm 0.13$ & $1.26 \pm 0.22$ & $P<0.05$ \\
\hline \multicolumn{4}{|l|}{ Peritubular cells } \\
\hline Total volume of tissue $\left(\mathrm{cm}^{3}\right)$ & $1.13 \pm 0.11$ & $2.24 \pm 0.24$ & $P<0.01$ \\
\hline
\end{tabular}

The yield of spermatogonial divisions, i.e. the number of leptotene primary spermatocytes produced by an $A_{1}$ spermatogonia, was greater in the autumn than the spring (Table 3). Similarly, the yield of meiosis and early spermiogenesis, i.e. the number of round spermatids at stage 8 produced by a leptotene primary spermatocyte, was also slightly greater in the autumn although the difference was not significant (Table 3). The yield of spermiogenesis doubled between spring and autumn (Table 3 ). 
The total volumes of the different components of the intertubular tissue were all significantly greater in the autumn-killed animals (Table 4) and there was an increase in the nuclear and cytoplasmic volume of the interstitial cells (Table 4).

\section{Discussion}

The histology of the testis of the stag is similar to that of the domestic ungulates. The two types of stem spermatogonia are nearly identical to those observed in the adult bull (Hochereau-de Reviers, 1970) and ram (Hochereau-de Reviers, Ortavant \& Courot, 1976). The relative frequencies of the stages of the seminiferous epithelium cycle are also similar, the divisions of the B-type spermatogonia into primary spermatocytes occurring at stage 1 as in ram and bull testis. However, the seasonal changes in the various components of the stag testis are more conspicuous than are those in the other species.

Both the seminiferous tubules and the intertubular tissue change markedly with the seasonal sexual cycle of the stag. While the Sertoli cell numbers remain constant in the adult animal, the numbers of the various germ cell types involved in spermatogenesis change with season. Outside the sexual season there is a decrease in the yield of the spermatogonial divisions, meiosis and spermiogenesis, as occurs in both the ram (Ortavant, 1958; Hochereau-de Reviers, Loir \& Pelletier, 1976) and vole (Grocock \& Clarke, 1975). The seasonal changes in the stem spermatogonia are of special interest because they differ from those described for the ram in which the total number of both $A_{0}$ and $A_{1}$ spermatogonia per testis increase in the sexual season (Hochereau-de Reviers et al., 1976).

The intertubular tissue of the testis is greatly expanded in the sexually active stags killed in the autumn. This is largely the result of changes in the Leydig cells which expand in both nuclear and cytoplamic mass; similar changes in the Leydig cells occur in sexually active hamsters (Vendrely Guerillot \& Da Lage, 1972). This Leydig cell hypertrophy in the stag coincides with the time when testicular testosterone concentrations are maximal (Lincoln, 1971b) and the blood levels of testosterone are also high (Lincoln \& Kay, 1979). In other seasonal breeders large increases in blood flow through the testis are known to occur during the sexual season (dormouse, ferret and fox: Joffre \& Joffre, 1973; Joffre, 1977; ram: Courot \& Joffre, 1977).

Seasonal changes in the pituitary content of LH (Bruggermann et al., 1965) and in the blood levels of LH (Lincoln \& Kay, 1979) occur in the stag, and it is possible that changes in gonadotrophin secretion dictate the seasonal cycle of testicular activity. It is not clear whether there is a direct effect of gonadotrophins on the efficiency of spermatogenesis or whether this effect is mediated via testosterone. The direct control of spermatogenesis by gonadotrophins is indicated by the observation in the ram that testosterone alone is unable to maintain spermatogonial divisions or fully support meiosis and spermiogenesis (Monet-Kuntz, Terqui, Locatelli, Hochereau-de Reviers \& Courot, 1976).

We thank the Nature Conservancy for arranging the cull of stags as required, and Mrs C. Perreau for expert technical assistance.

\section{References}

Abercrombie, M. (1946) Estimation of nuclear popula* tion from microtome sections. Anat. Rec. 94, 238-248.

Attal, J. \& Courot, M. (1963) Dévelopment testiculaire et établissment de la spermatogénèse chez le taureau. Annls Biol. anim. Biochim. Biophys. 3, 219-241.

BruggermanN, J., Adam, A. \& Karg, G.H. (1965) I.S.C.H. Bestimungen in hypophysen von rehböcken (Capreolus capreolus) and hursehen (Cervus elaphus) unter Berückstichtigung des saisoneinflusses. Acta endocr., Copenh. 48, 569-580.

Clermont, Y. (1967) Cinétique de la spermatogénèse chez les Mammiféres. Archs Anat. microsc. Morph. exp. 56, Suppl. 3-4, 7-60.

COURot, M. \& Joffre, M. (1977) Testicular capillary blood flow in the impubertal lamb and the ram during the breeding and non-breeding seasons. Andrologia 9, 332-336.

Frankenberger, Z. (1953) Pohlavni cyklus jelene (Cervus elaphus L.). Čslká Morf. 1, 28-34.

GrocoCK, C.A. \& ClARKE, J.R. (1975) Spermatogenesis in mature and regressed testes of the yole (Microtus agrestis). J. Reprod. Fert. 43, 461-470. via free access 
Hennig, A. (1957) Das Problem des Kern messung. Eine Zusammenfessung and Erweiterung der mikroskopischen Messtechnik. Mikroskopie 12, 174 203.

Hochereau-de Reviers, M.T. (1970) Etude des divisions spermatogoniales et du renouvellement de la spermatogonie souche chez le Taureau. These, Dr. es Sciences, Paris, CNRS No. 3976.

Hochereau-de Reviers, M.T., Ortavant, R. \& Courot, M. (1976) Type A spermatogonia in the ram. Sperm Action Prog. Reprod. Biol. 1, 13-19.

hochereau-de Reviers, M.T., Loir, M. \& Pelletier, J. (1976) Seasonal variations in the response of the testis and $\mathrm{LH}$ levels to hemicastration of adult rams. J. Reprod. Fert. 46, 205-209.

Joffre, J. \& Joffre, M. (1973) Seasonal changes in the testicular blood flow of seasonally breeding mammals: dormouse (Glis glis), ferret (Mustela furo) and fox (Vulpes vulpes), J. Reprod. Fert. 34, 227-233.

JofFRE, M. (1977) Relationship between testicular blood flow, testosterone secretion and spermatogenic activity in young and adult wild red foxes (Vulpes vulpes). J. Reprod. Fert. 51, 35-50.

Lincoln, G.A. (197la) Puberty in a seasonally breeding male, the red deer stag (Cervus elaphus L.). J. Reprod. Fert. 25, 41-54.

LiNCOLN, G.A. (1971b) The seasonal reproductive changes in the red deer stag (Cervus elaphus L.). J. Zool., Lond. 163, 105-123.

LiNCOLN, G.A. (1978) The temporal relationship between plasma levels of FSH and $\mathrm{LH}$ in the ram. J. Reprod. Fert. 53, 31-37.
LiNCOLN, G.A. \& KAY, R.N.B. (1979) Effects of season on the secretion of $\mathrm{LH}$ and testosterone in intact and castrated red deer stags (Cervus elaphus). $J$. Reprod. Fert. 55 (in press).

LINDNER, H.R. \& MANN, T. (1960) The relationship between content of androgenic steroids in the testis and the secretory activity of the seminal vesicles in the bull. $J$. Endocr. 21, 341-360.

MANN, T., Rowson, L.E.A., ShORT, R.V. \& Skinner, J.D. (1967) The relationship between nutrition and androgenic activity in pubescent twin calves and the effect of orchitis. J. Endocr. 38, 455-468.

Monet-Kuntz, C., Terqui, M., Locatelli, A., Hochereau de Reviers, M.T. \& Courot, M. (1976) Effet de la supplementation en testostérone sur la spermatogénèse de Bélier hypophysectomisé. $C$. $r$. hebd. Séanc. Acad. Sci., Paris 283, 1763-1766.

ORTAVANT, R. (1958) Le cycle spermatogénétique chez le Bélier. Thése, Dr. es Sciences, Paris, CNRS A 3118.

Roosen-Runge, E.C. \& Giesel, L.O. (1950) Quantitative studies on spermatogenesis in the albino rat. Am. J. Anat. 87, 1-30.

Scaramuzzi, R.J., Caldwell, B.V. \& Moor, R.M. (1970) Radioimmunoassay of $\mathrm{LH}$ and estrogen during the estrous cycle in the ewe. Biol. Reprod. 3, 110-119.

SNedecor, G.W. \& Cochran, W.G. (1957) Statistical Methods. Iowa State University Press, Ames.

Vendrely, E., Gúfillot, C. \& DA LAGe, C. (1972) Variations saisonnières de cellules de Sertoli et de Leydig dans le testicule de hamster doré. Etude caryometrique. C. r. hebd. Séanc. Acad. Sci., Paris 275, 1143-1146. 